\title{
PUBLIC AND POSTCOLONIAL PRACTICES IN LATIN AMERICAN ARCHAEOLOGY: ENGAGING WITH NON-DESCENDANT COMMUNITIES IN NORTHERN BELIZE*
}

\author{
PRÁCTICAS PÚBLICAS Y POSTCOLONIALES EN LA ARQUEOLOGÍA \\ LATINOAMERICANA: COLABORANDO CON COMUNIDADES \\ NO-DESCENDIENTES EN EL NORTE DE BELICE
}

\author{
Maxine Oland $^{1}$
}

\begin{abstract}
The modern villages of San Estevan and Progresso, Belize, are located on and around archaeological sites. Ancient Maya material culture is a daily reality for village residents, yet residents claim no ancestral or ethnic ties to the archaeological remains. This essay reflects on the experience of conducting archaeological investigations in these two non-descendant communities, and on efforts at public engagement during the course of research. It shows the evolving views of one archaeologist as she seeks to decolonize her future research practices.
\end{abstract}

Key words: Belize, Maya, communities, decolonizing archaeology, public archaeology.

Las aldeas de San Estevan y de Progresso, Belice, están situadas en y alrededor de sitios arqueológicos. Los materiales culturales antiguos mayas conforman parte de una realidad cotidiana para los residentes de las aldeas, sin embargo, los residentes no tienen vínculo ancestral o étnico a los restos arqueológicos. En este ensayo se reflexiona sobre la experiencia de hacer una investigación arqueológica en las dos comunidades nodescendientes, así como sobre los esfuerzos de participación pública en el transcurso de la investigación. Se muestra la evolución de las ideas de una arqueóloga que busca descolonizar sus prácticas de investigaciones futuras.

Palabras claves: Belice, Maya, comunidades, descolonización de la arqueología, arqueología pública.

The influence of postcolonial theory has brought attention to the ways that archaeology contributed to, and benefited from, Western colonial policies and structures (Gosden 2001; Liebmann and Rizvi 2008). With recognition of our discipline's history of "scientific colonialism" (Nicholas and Hollowell 2007; Zimmerman 2001), some archaeologists have set out to decolonize archaeological practice (Apffel-Marglin and Marglin 1996; Atalay 2006; Nicholas 2008; Nicholas and Andrews 1997; Smith and Jackson 2006; Smith and Wobst 2005; Tuhiwai Smith 1999). Decolonizing archaeology entails the recognition of the colonial structures that have shaped our discipline, and actively working to subvert such structures. This often takes the shape of redistributing power, so that decisions about the subjects, methodologies, and interpretations of archaeological research are made by local or descendant communities, rather than exclusively by the archaeologists.

There is a growing body of work devoted to collaborative and cooperative relationships, and ongoing dialogues between researchers and indigenous or descendant populations (e.g., Colwell-Chanthaphonh and Ferguson 2008; Kerber 2006; Marshall 2002; McDavid 2002; Moser et al. 2002; Silliman 2008; Stoughton 2006; Watkins 2000, 2003). Yet in many places in which archaeology is done today, local people do not claim an ancestral connection to ancient inhabitants (e.g., Hutson 2010; Pyburn 2003; Watkins et al. 2000; Parker-Pearson and Ramilisonina 2004). Such is the case in much of Latin America, where

* Artículo seleccionado del conjunto de ponencias presentadas en el Simposio Shifting from Object-centered Research to People-focused Application: Current Approaches to Public Archaeology from Latin America and the Caribbean, realizado en el marco de la 75 reunión anual de la Sociedad de Arqueología Americana, Saint Louis, Missouri, EUA, abril 2010. Este manuscrito fue evaluado por investigadores externos y editado por Reiko Ishihara-Brito y Cameron Griffith, en su calidad de editores invitados de la Revista.

1 Department of Anthropology, Smith College, Northampton, Massachusetts 01063, USA. moland@ smith.edu, Maxine.Oland@gmail.com 
processes of epidemic disease, colonization, migration, forced resettlement, and national, political, and intellectual discourses about mestizaje (a "mixed" Spanish/indigenous ethnic identity) have created a disconnect between pre-Columbian/historic peoples and contemporary populations.

Archaeologists seeking to decolonize archaeology aim to correct the power imbalances of our discipline left over from colonial structures. These imbalances get played out in non-descendant communities in Latin America and elsewhere. While completing my dissertation research, between 2001 and 2003, I spent every summer living and working in two non-descendant communities in northern Belize as an archaeologist. Each summer I did some public archaeology, explaining our research goals and excavation results, allowing local residents to see and touch our finds.

In the years since completing this research I have thought back to my work, and have observed the growing field of community archaeology and scholars seeking to decolonize our field. This essay is a critical reflection on my experiences, with an eye toward changing my practices in future research, and considering the challenges of decolonizing practices in non-descendant communities. At the same time, I recognize my own colonial gaze and the paradox of discussing decolonization without yet collaborating with local communities. I have framed much of this essay in the first person, in an effort to avoid speaking for the communities about which I write.

In this article, I briefly discuss the two Belizean communities (Figure 1) in which I worked and lived while completing my archaeological research. I argue that even though residents self-identify as neither indigenous nor descendant, there are important heritage needs in these communities. Finally, I explore the challenges to changing my archaeological practices in light of these heritage concerns.

\section{Where the Roads are Paved with Maya Temples}

San Estevan is one of many communities in Latin America located on top of pre-Columbian or historic-period archaeological remains. Until the Belize Department of Archaeology intervened in the late 1990s, the monumental core of the Early Classic Period site of San Estevan was bulldozed for road fill. The streets of San Estevan are quite literally paved with Maya temples. Archaeologists have worked intermittently at and around the village

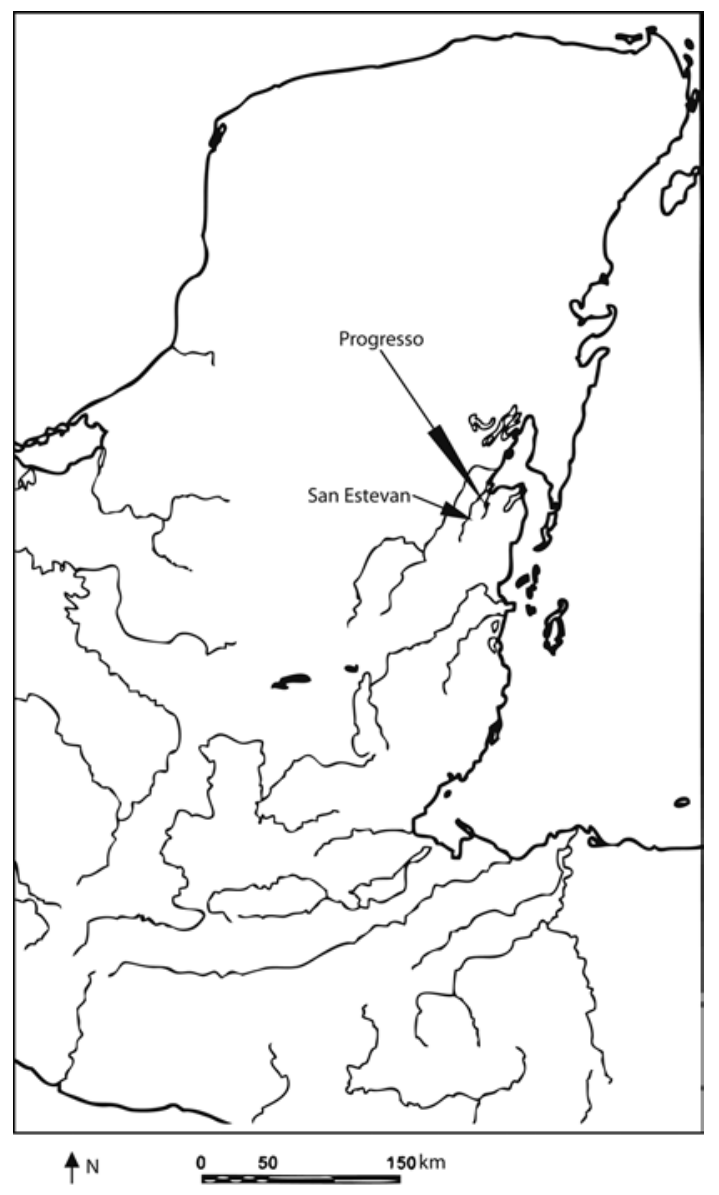

Figure 1. Map showing the location of Progresso and San Estevan, Belize.

Mapa que muestra la ubicación de Progresso y San Estevan, Belice.

since the 1960s (Bullard 1965; Hammond 1973, 1975; Levi 1996, 2002, 2003; Rosenswig 2007, 2008). In addition, San Estevan has served as the home base for archaeological teams working at Progresso Lagoon, Honey Camp Lagoon, and Pulltrouser Swamp. Archaeological remains are part of residents' everyday lives. Archaeological research -and archaeologists- are woven into the social and economic history of the community.

The village of Progresso was also built adjacent to Maya ruins. The town itself was established during the Caste War of Yucatán (AD 1847-1901), and has remnants of architecture dating to this period (Masson 1998). Between 1997 and 2003, archaeologists completed survey and excavation along the shores of Progresso Lagoon, and on Caye Coco, the largest island in the lagoon (Delu et al. 2002; Ferguson et al. 2003; Masson and Rosenswig 
1998, 1999; Oland and Masson 2005; Rosenswig and Masson 2000, 2001).

Although we worked with the consent of landowners and hired some laborers from Progresso, in other ways archaeologists avoided local community relations with Progresso. Between 1997 and 2002, the archaeological project was based in the town of San Estevan, and archaeologists commuted to the outskirts of Progresso for research. Research was conducted on land just south of the town center, on the island of Caye Coco (the site of a homestead farm), and on agricultural fields (primarily sugarcane) owned by Progresso villagers. Between 2000 and 2003, much of the research was conducted on fifteenth- to seventeenth-century Maya remains, which were located on large estate properties owned by outsiders (American, Jamaican, and Belizean). The acquisition of lagoon property by non-local owners has increased in recent years, and complicates community relations and politics.

In 2002, the project held an outreach Museum Night in Progresso, and in 2003 the project based its living quarters in the village. The movement of the camp to Progresso in 2003 was extremely successful, and members of the community seemed to appreciate the money that we spent there for archaeological and domestic labor, rent, food, and other supplies. Nonetheless, this economic impact was not sustained, as no archaeological research has been undertaken at Progresso Lagoon since 2003.

\section{"Look What I Found in my Field": Archaeology is Interesting}

Many residents of San Estevan and Progresso are interested in the ancient artifacts and altered landscapes that are spread across their yards and fields. My colleagues and I have been approached many times to look at mounds and artifacts, particularly obsidian blades, ceramic or stone beads, and fragments of ceramic effigy-style incense burners. Archaeological remains are sometimes collected, much as residents of my New England town will collect fragments of nineteenth-century pottery or glass from their own backyards.

On the one hand, archaeological remains are curiosities. On the other, archaeologists and heritage organizations like the UNESCO World Heritage Committee have argued for decades that archaeology, particularly prehistory, belongs to everyone (and that its loss is a detriment to all of us) (e.g., Brodie and Renfrew 2005). Some residents expressed pride that the ruins around their village were important to the scientific community, and to the study of the prehistory and history of the Maya people. This pride was evident when residents were given copies of field reports, in which landowners saw their own properties featured.

The government of Belize has also tried to preserve its archaeological patrimony as a means of building a national identity. The government maintains and regulates archaeological sites through the Institute of Archaeology, National Institute of Culture and History, and argues that "the study [of] the past provides a foundation for our understanding of Belize's Cultural Heritage" (Belize Institute of Archaeology n.d.). The past two decades have seen national investment in the infrastructure of Belize's museums, Houses of Culture, and archaeological parks.

If archaeology is part of nation-building and national pride, then having an archaeological site in one's community can contribute to that national pride. Certainly this is not the case for everyone, as many populations are left out of the national story of multicultural diversity in Belize (see Medina 1997). Yet there is not a clear connection between the nation's promotion of Maya archaeology as national heritage and contemporary ethnic identity. The work of the Maya Area Cultural Heritage Initiative (MACHI, now InHerit) has suggested that many contemporary ethnic Maya in southern Belize do not see archaeological sites as important to contemporary identity (Parks 2010; Parks et al. 2006). The government of Belize has to some degree succeeded in transforming Maya archaeology into national heritage, while keeping it distinct and distant from the thorny issues of indigenous Maya land rights and cultural patrimony in southern Belize.

\section{"Why Don't you Dig those Bigger Mounds Over There?": Archaeological Tourism}

It is hard to avoid the association of archaeological sites with tourism in Belize. Over the past two decades, reconstructive work at Altun Ha, Lamanai, and Cerros has brought an increasing number of visitors to northern Belize. Residents are aware that in some places, whole villages have mobilized to serve the tourist needs of visitors on day trips from cruise ships (i.e. the village of Indian Church at the archaeological site of Lamanai). Why not Progresso Lagoon? While I conducted my dissertation fieldwork, I was repeatedly asked why I 
did not dig bigger mounds? Why didn't I excavate something that tourists would want to come visit?

Of course, the creation of archaeological tourist attractions is not as easy as digging large mounds. In Belize, archaeological tourism is primarily controlled by the aforementioned Institute of Archaeology, which maintains twelve archaeological parks across the country. Tourism industries (such as hotels, restaurants, and tour companies) have developed around these parks, but are not typically placed around undeveloped ruins (see Ramsey and Everitt 2008). Most ancient Maya sites remain on privately held land, and are unexcavated and unconsolidated. At Progresso Lagoon, many people anticipated that they would benefit from archaeological tourism. There was, however, some fear of land being taken away by the government of Belize if we did find anything of consequence (particularly among non-Belizean landowners).

\section{"I Heard about this One Jade Piece...": Subsistence Digging and the Antiquities Trade}

Others see artifacts as a source of income, and looting pits pockmark the region. As the illegal trade in pre-Columbian artifacts continues (Coggins 1969; Gilgan 2001; Pendergast 1991; Pendergast and Graham 1989), and may in fact increase in times of market volatility (see Pendergast 1991), some local residents engage in unauthorized digging to fill the demand (see Parks et al. 2006). Yet ethnographers have found that many local looters are "subsistence diggers": they loot archaeological sites to support their households because few other viable economic alternatives exist (Hollowell 2006; Hollowell-Zimmer 2003; Matsuda 1998a, b).

The presence of archaeologists may in fact unintentionally encourage looting (Hollowell 2006:86) (although the opposite appears to be true among schoolchildren with access to archaeologists and archaeological research in Crooked Tree, Belize; Alicia Beth Ebbitt McGill personal communication August 2011). Archaeologists often swoop in for short seasons, train and pay local laborers to remove "important" artifacts, and then leave the community with few, if any, long-term economic benefits. Looters may see looting as a form of "economic justice" to take and sell these artifacts (Hollowell 2006:76; Matsuda 1998a:93). Why should archaeologists be the only ones to benefit from archaeological remains? Despite the law in Belize that all cultural heritage more than 100 years old belongs to the government, local people often feel that they have a right to harvest the artifacts from their own lands (Matsuda 1998a, b; Parks 2010).

During the 2003 field season, my excavations were looted one night after we had left the site, although it is doubtful that anything of consequence was found. Other looter's pits are scattered around the shore of Progresso Lagoon, and on Caye Coco. Whether these were placed in reaction to archaeologists' presence in the area, or in response to the dire economic realities of many residents, they express a desire for archaeological heritage to be an economic resource, and a desire to be in control of this resource.

\section{Considering my Role in a Decolonized Archaeology}

When I designed my archaeological research in Belize, I did not consider the heritage needs of the communities in which I lived and work. My archaeological practice, however was influenced by Anne Pyburn and Richard Wilk's (1995) idea of "Archaeology as Applied Anthropology." Their approach asks us to consider the role that archaeologists play in a community, and to act in a way that is responsible to the people amongst whom we live and work. For me, this has meant training staff and students to interact appropriately according to the norms of the village, and to respect the customs of our neighbors. When given this direction, I found that staff and students went above and beyond expectations, and made substantial efforts to participate in community life.

It also meant recognizing the financial impact of our archaeological project on the community. When I came to the community with substantial grant funding, I was careful to institute equitable hiring practices. Members of the community were all given an equal opportunity to apply for work, and men and women were hired in the order in which they applied. Students and staff were also encouraged to patronize multiple stores in towns, as a way to more equally distribute the wealth that we brought with us.

Inspired by the growing field of public archaeology, I sought a way to disseminate project information with our local communities while archaeological research was occurring. I began the tradition of Museum Night, during which staff 
and students would display and explain artifacts from the current season's excavations to the local community. I gave lectures in English and Spanish about our goals, our methodologies, and our findings to date. Young children colored in pictures of artifacts. The village youth group sold drinks and snacks. Although it was simple, this was an attempt to present the community with the information I thought they needed to know.

As an academic archaeologist, I did what was expected of me, and beyond, by engaging in the community. But when situated within the field of decolonizing practice, my work falls short. Although our large turnouts indicated an appreciation for our efforts, the power to create, interpret, and disseminate the history of this place rested solely with me. I did not plan my research around the archaeological interests of the local residents, nor did I ask them what they wanted to know. Because I worked amongst non-descendant communities, nobody (i.e. advisers, colleagues, the Belize government) expected me to collaborate with them in the investigation of the past.

\section{Decolonizing Archaeological Practice}

Decolonizing means creating a discourse and collaboration between researchers and communities, to fundamentally shift the relations of power. While this is increasingly expected in indigenous communities, it is far less often attempted in non-descendant communities. Laurajane Smith (2006:44) refers to heritage as "a cultural process that engages with acts of remembering... to create ways to understand and engage with the present." Put this way, non-descendant communities have as much right to engage with archaeological heritage as an ancestral or indigenous community.

Mike Parker Pearson and Ramilisonina (2004) urge us to work with the local community rather than for any particular indigenous or ethnic group. They stress the possibility of meeting both the needs of the greater archaeological community and the particular needs of the local population, while avoiding reinforcing any one minority or dominant ideology. This approach entails a definition of heritage that is not tied to ancestral or genetic continuities, but which encompasses everything about the past that may be important to present-day peoples (Smith 2006). Some scholars (e.g., Chilton and Hart 2009; Hart 2009, 2011) envision local communities to be made up of multiple archaeological stakeholders defined as anyone with an interest in the heritage work done by and with archaeological remains. The concept of stakeholders helps to recognize the competing interests that may be represented by community members.

What would a decolonized practice look like in my work? I would like to be part of the heritage work in San Estevan and Progresso: to collaborate with them, and to use my expertise in a way that is acceptable and beneficial to multiple stakeholders. This would require large investments in building relationships, and in researching the heritage needs and interests of stakeholders. It would be hard to accomplish the necessary level of communication and interaction within the confines of the busy two-month field season. Such an undertaking would require a much longer time period, many conversations, and perhaps a researcher dedicated to the these tasks.

I can anticipate the challenges of such a project in San Estevan and Progresso, where divisions along political party lines, socioeconomic class, and other historical divisions will surely create distinct stakeholder interests (see also Ardren 2002; Breglia 2007). In addition, the two communities differ from each other, in income levels, ethnic background, and in the interactions they have had with archaeologists.

When I return to my research, I will have to confront questions such as: is an archaeologist more responsible to the community one lives in, or the community one excavates in? With a regional project, it is likely that excavations will take place in various locations throughout the years. Yet heritage needs are likely to be more local than regional.

Furthermore, I anticipate that the heritage needs of the communities will be different from my research goals. I do believe that local residents of Progresso and San Estevan are interested in archaeology as an intellectual pursuit. Turnout was always large at my public events. People asked questions about how ancient people lived in Belize, and how artifacts were used. There seemed to be pride associated with being part of a regional and national cultural heritage. On the other hand, the economic reality of most rural Belizeans surpasses the academic interest of an educated public. My observations suggest that local residents are interested in harnessing archaeological resources for economic benefit. While some residents have turned to subsistence 
digging to supplement their income, many others look to the significant impact that archaeological tourism can have on a local economy. As an academic archaeologist, I am uncomfortable engaging in archaeology solely for the purpose of attracting tourists, particularly knowing the profound and unexpected changes that have accompanied tourism in other Belizean communities (see Medina 2003).

\section{Conclusion}

San Estevan and Progresso are like so many other communities around the world, where residents live amongst the archaeological past, but do not claim to be the ancestors of the previous inhabitants. In this essay I have proposed a focus on local heritage needs, but anticipate the challenges of engaging with a multivocal and diverse public. The questions looming over my future work are many, and I am sure that such a decolonizing project is much more complicated than I have imagined. Yet if we are to move beyond the colonial constructs of our disciplinary history, it strikes me as important to start taking the heritage needs of these communities seriously.

Acknowledgments: My research in Belize has been made possible by the Belize Institute of Archaeology, under the direction of John Morris, George Thompson, and Jaime Awe. Field research was accomplished with support from the Belize Postclassic Project and the SUNY Albany Field School, directed by Marilyn Masson, the National Science Foundation Dissertation Improvement Grant (\#0315331), a dissertation grant from the Wenner-Gren Foundation for Anthropological Research (\#7055), and Northwestern University. I am incredibly grateful to the people of San Estevan and Progresso, Belize. I thank Alicia Beth Ebbitt McGill, Elizabeth Klarich, Siobhan Hart, Cameron Griffith, and Reiko Ishihara-Brito for their comments on earlier versions of this paper.

\section{References Cited}

Apffel-Marglin, F., and S.A. Marglin (eds.) 1996. Decolonizing Knowledge: From Development to Dialogue. Clarendon Press, Oxford.

Ardren, T. 2002. Conversations about the production of archaeological knowledge and community museums at Chunchucmil and Kochol, Yucatán, México.World Archaeology 34:379-400.

Atalay, S. 2006. Indigenous archaeology as decolonizing practice. American Indian Quarterly 30(3/4):280-310.

Belize Institute of Archaeology n.d. Education and communication. Institute of Archaeology, National Institute of Culture and History, Belmopan, Belize. http://www.nichbelize.org/ education-communication/education-and-communications.html (25 August 25 2011).

Breglia, L.C. 2007. Engaging local communities in archaeology: Observations from a Maya site in Yucatán, México. In Past Meets Present: Archaeologists Partnering with Museum Curators, Teachers, and Community Groups, edited by J.H. Jameson and S. Baugher, pp. 89-99. Springer, New York.

Brodie, N., and C. Renfrew 2005. Looting and the world's archaeological heritage: The inadequate response. Annual Review of Anthropology 34:343-361.

Bullard, W.R., Jr. 1965. Stratigraphic Excavations at San Estevan, Northern British Honduras. Royal Ontario Museum Occasional Paper 9. University of Toronto, Toronto.

Chilton, E.S., and S.M. Hart 2009. Crafting collaborative archaeologies: Two case studies. Collaborative Anthropologies 2:87-108.
Coggins, C.1969. Illicit traffic of pre-Columbian antiquities. Art Journal 29(1):94, 96, 98, 114 (http://www.jstor.org/ discover/10.2307/775285).

Colwell-Chanthaphonh, C., and T.J. Ferguson (eds.) 2008. Collaboration in Archaeological Practice: Engaging Descendant Communities. Altamira Press, Lanham, Maryland.

Delu, A.M., B.W. Russell, and M.A. Masson (eds.) 2002. Belize Postclassic Project 2001: Investigations at Caye Coco and the Shore Settlements of Progresso Lagoon. Report to the Department of Archaeology, Belmopan, Belize. Institute for Mesoamerican Studies Occasional Publication $N^{\circ} 7$. The University at AlbanySUNY, Albany, New York.

Ferguson, J.M., M.H. Oland, and M.A. Masson (eds.) 2003. Belize Postclassic Project 2002: Investigation of the Shore Settlements of Progresso Lagoon, and San Estevan. Report to the Department of Archaeology, Belmopan, Belize. Institute for Mesoamerican Studies Occasional Publication $\mathrm{N}^{\circ}$ 9. The University at Albany-SUNY, Albany, New York.

Gilgan, E. 2001. Looting and the market for Maya objects: A Belizean perspective. In Trade in Illicit Antiquities: The Destruction of the World's Archaeological Heritage, edited by N. Brodie, J. Doole, and C. Renfrew, pp. 73-88. McDonald Institute Monographs for Archaeological Research, Cambridge.

Gosden, C. 2001. Postcolonial archaeology: Issues of culture, identity, and knowledge. In Archaeological Theory Today, edited by I. Hodder, pp. 241-261. Polity Press, Cambridge. 
Hammond, N. (ed.) 1973. Corozal Project: 1973 Interim Report. Manuscript on file at Cambridge University.

- - - 1975. Maya settlement hierarchy in northern Belize. In Studies in Ancient Mesoamerica, II, edited by J.A. Graham, pp. 40-55. University of California, Berkeley.

Hart, S.M. 2009. High stakes: A poly-communal archaeology of the Pocumtuck Fort, Deerfield, Massachusetts. Doctoral Dissertation, University of Massachusetts, Amherst.

- - - 2011. Heritage, neighborhoods and cosmopolitan sensibilities: Poly-communal archaeology in Deerfield, Massachusetts. Present Pasts 3:26-34.

Hollowell, J. 2006. Moral arguments on subsistence digging. In The Ethics of Archaeology: Philosophical Perspectives on Archaeological Practice, edited by C. Scarre, and G. Scarre, pp. 69-93. Cambridge University Press, Cambridge.

Hollowell-Zimmer, J. 2003. Digging in the dirt-ethics and "lowend looting". In Ethical Issues in Archaeology, edited by L.J. Zimmerman, K.D. Vitelli, and J. Hollowell-Zimmer, pp. 45-56. Altamira Press, Walnut Creek, California.

Hutson, S.R. 2010. Dwelling, Identity, and the Maya: Relational Archaeology at Chunchucmil. Altamira Press, Lanham, Maryland.

Kerber, J.E. (ed.) 2006. Cross Cultural Collaboration: Native Peoples and Archaeology in the Northeastern United States. University of Nebraska Press, Lincoln.

Levi, L.J. 1996. Sustained production and residential variation: A historical perspective on lowland Maya domestic economy. In Managed Mosaic, edited by S. Fedick, pp. 92-106. University of Utah Press, Salt Lake City.

- - - 2002. An institutional perspective on prehispanic Maya residential variation: Settlement and community at San Estevan, Belize. Journal of Anthropological Archaeology 21:120-141.

- - - 2003. Space and the limits to community. In Perspectives on Ancient Maya Rural Complexity, edited by G. Iannone, and S.V. Connell, pp. 82-93. Cotsen Institute of Archaeology, Los Angeles.

Liebmann, M., and U.Z. Rizvi (eds.) 2008. Archaeology and the Postcolonial Critique. Altamira Press, Lanham, Maryland.

McDavid, C. 2002. Archaeologies that hurt; descendants that matter: A pragmatic approach to collaboration in the public interpretation of African-American archaeology. World Archaeology 34:303-314.

Marshall, Y. 2002. What Is community archaeology? World Archaeology 34:211-219.

Masson, M.A. 1998. Caste War Church, Progresso Lagoon. In Belize Postclassic Project 1997: Laguna de On, Progresso Lagoon, Laguna Seca. Institute of Mesoamerican Studies Occasional Publication $\mathrm{N}^{\circ}$ 2, edited by M.A. Masson, and R.M. Rosenswig, pp. 131-136. The University at Albany-SUNY, Albany, New York.

Masson, M.A., and R.M. Rosenswig (eds.) 1998. Belize Postclassic Project 1997 : Laguna de On, Progresso Lagoon, Laguna Seca. Report to the Department of Archaeology, Belmopan, Belize. Institute for Mesoamerican Studies Occasional Publication $\mathrm{N}^{\circ} 2$. The University at Albany-SUNY, Albany, New York.

- - - 1999. Belize Postclassic Project 1998: Investigations at Progresso Lagoon. Report to the Department of Archaeology,
Belmopan, Belize. Institute for Mesoamerican Studies Occasional Publications $\mathrm{N}^{\circ}$ 3. The University at Albany-SUNY, Albany, New York.

Matsuda, D. 1998a. The ethics of archaeology, subsistence digging, and artifact looting in Latin America. International Journal of Cultural Property 7:89-98.

- - - 1998b. Subsistence Digging in and around Belize. Doctoral Dissertation, The Union Institute, School of Interdisciplinary Arts and Sciences, Cincinnati.

Medina, L.K. 1997. Development policies and identity politics: Class and collectivity in Belize. American Ethnologist 24:148-169.

- - - 2003. Commoditizing culture: Tourism and Maya identity. Annals of Tourism Research 30:353-369.

Moser, S., D. Glazier, J.E. Phillips, L.N. el Nemr, M.S. Mousa, R.N. Aiesh, S. Richardson, A. Conner, and M. Seymour 2002. Transforming archaeology through practice: Strategies for collaborative archaeology and the Community Archaeology Project at Quseir, Egypt. World Archaeology 34:220-248.

Nicholas, G., and J. Hollowell 2007. Ethical challenges to a postcolonial archaeology: The legacy of scientific colonialism. In Archaeology and Capitalism: From Ethics to Politics, edited by Y. Hamilakis, and P. Duke, pp. 59-82. One World Archaeology. Left Coast Press, Walnut Creek, California.

Nicholas, G.P. 2008. Native peoples and archaeology. In Encyclopedia of Archaeology, Vol. 3, edited by D.M. Pearsall, pp. 1660-1669. Elsevier, New York.

Nicholas, G.P., and T.D. Andrews 1997. At a Crossroads: Archaeology and First Peoples in Canada. Archaeology Press, Burnaby.

Oland, M.H., and M.A. Masson (eds.) 2005. Belize Postclassic Project 2003: Investigations on the West Shore of Progresso Lagoon. Report to the Institute of Archaeology, Belmopan, Belize. Institute for Mesoamerican Studies Occasional Publication $\mathrm{N}^{\circ}$ 10. The University at Albany-SUNY, Albany, New York.

Parker Pearson, M., and Ramilisonina 2004. Public archaeology and indigenous communities. In Public Archaeology, edited by N. Merriman, pp. 224-239. Routledge, London.

Parks, S. 2010. The collision of heritage and economy at Uxbenká, Belize. International Journal of Heritage Studies 16(6):434-448.

Parks, S., P.A. McAnany, and S. Murata 2006. The conservation of Maya cultural heritage: Searching for solutions in a troubled region. Journal of Field Archaeology 31:425-432.

Pendergast, D.M. 1991. And the loot goes on: Winning some battles but not the war. Journal of Field Archaeology 18:89-95.

Pendergast, D.M., and E. Graham 1989. The battle for the Maya past: The effects of international looting and collecting in Belize. In The Ethics of Collecting Cultural Property: Whose Culture? Whose Property?, edited by P.M. Messenger, pp. 51-60. University of New Mexico Press, Albuquerque.

Pyburn, K.A. 2003. Archaeology for a new millenium: The rules of engagement. In Archaeologists and Local Communities: Partners in Exploring the Past, edited by L. Derry and M. Malloy, pp. 167-184. The Society for American Archaeology, Washington, D.C. 
Pyburn, K.A., and R.R. Wilk 1995. Responsible archaeology is applied anthropology. In Ethics in American Archaeology, edited by M.J. Lynott and A. Wylie, pp. 78-83. Society for American Archaeology, Washington, D.C.

Ramsey, D., and J. Everitt 2008. If you dig it, they will come!: Archaeology heritage sites and tourism development in Belize, Central America. Tourism Management 29(5):909-916.

Rosenswig, R.M. 2007. San Estevan Archaeological Project 2005. Institute of Mesoamerican Studies, Occasional Publication $\mathrm{N}^{\mathrm{o}} 14$. The University at Albany-SUNY, Albany.

- - - 2008. San Estevan Archaeological Project 2008. Institute of Mesoamerican Studies Occasional Publication $N^{\circ} 15$. The University at Albany-SUNY, Albany.

Rosenswig, R.M., and M.A. Masson (eds.) 2000. Belize Postclassic Project 1999: Continued Investigations at Progresso Lagoon and Laguna Seca. Report to the Department of Archaeology, Belmopan, Belize. Institute for Mesoamerican Studies Occasional Publication $N^{\circ}$ 5. The University at Albany-SUNY, Albany, NY.

- - - 2001. Belize Postclassic Project 2000: Investigations at Caye Coco and the Shore Settlements of Progresso Lagoon. Report to the Department of Archaeology, Belmopan, Belize. Institute for Mesoamerican Studies Occasional Publication $\mathrm{N}^{\circ} 6$. The University at Albany-SUNY, Albany, New York.

Silliman, S.W. (ed.) 2008. Collaborating at the Trowel's Edge: Teaching and Learning in Indigenous Archaeology. University of Arizona Press, Tucson.
Smith, C., and G. Jackson 2006. Decolonizing indigenous archaeology: Developments from down under. American Indian Quarterly 30(3\&4):311-349.

Smith, C., and H.M. Wobst (eds.) 2005. Indigenous Archaeologies: Decolonizing Theory and Practice. Routledge, London.

Smith, L.2006. Uses of Heritage. Routledge, London.

Stoughton, S. 2006. Community archaeology: The Kitikmeot Heritage Society's Iqaluktuuq Project. Totem: The University of Western Ontario Journal of Anthropology 14(1):83-90.

Tuhiwai Smith, L. 1999. Decolonizing Methodologies: Research and Indigenous Peoples. Zed Books, London.

Watkins, J.E. 2000. Indigenous Archaeology: American Indian Values and Scientific Practice. Altamira Press, Walnut Creek, California.

- - - 2003. Beyond the margin: American Indians, First Nations, and archaeology in North America. American Antiquity 68:273-285.

Watkins, J., K.A. Pyburn, and P. Cressey 2000. Community relations: What the practicing archaeologist needs to know to work effectively with local and/or descendant communities.In Teaching Archaeology in the Twenty-First Century, edited by S.J. Bender, and G.S. Smith, pp. 73-81. Society for American Archaeology, Washington, D.C.

Zimmerman, L.J. 2001. Usurping Native American voice. In The Future of the Past: Archaeologists, Native Americans, and Repatriation, edited by T.L. Bray, pp. 169-184. Garland, New York. 